\title{
Timing of cholecystectomy after percutaneous cholecystostomy for acute cholecystitis- A systematic review and meta-analysis
}

Dr. Bhavin Vasavada,

Consultant hepatobiliary and liver transplant surgeon,

Department of hepatobiliary and liver transplant surgery,

Shalby Hospitals,

Ahmedabad.

Email: drbhavin.liversurgeon@gmail.com.

Dr. Hardik Patel

Consultant hepatobiliary and liver transplant surgeon,

Department of hepatobiliary and liver transplant surgery,

Shalby Hospitals,

Ahmedabad.

Conflict of interest: None

Funding disclosure: none

Keywords: percutaneous cholecystostomy, cholecystectomy, cholecystitis, early cholecystectomy. 


\section{Abstract:}

\section{Introduction:}

There is a controversy about the optimum timing of cholecystectomy after percutaneous cholecystostomy.

This systematic review and meta-analysis aimed to evaluate outcomes of early versus late cholecystectomy after percutaneous cholecystostomy.

\section{Methods:}

The study was conducted according to the Preferred Reporting Items for Systematic Reviews and Meta-Analyses (PRISMA) statement and MOOSE guidelines. Heterogeneity was measured using $\mathrm{Q}$ tests and I2 statistics. The random-effects model was used. We evaluated cholecystectomy performed at different periods after percutaneous cholecystostomy within 72 hours or later, within or after one week or percutaneous cholecystostomy, within 10 days or after 10 days, less than 2 weeks or more than 2 weeks, less than 4 weeks or more than 4 weeks, less than 8 weeks or more than 8 weeks as per literature.

\section{Results:}


medRxiv preprint doi: https://doi.org/10.1101/2021.06.06.21258426; this version posted June 12, 2021. The copyright holder for this preprint (which was not certified by peer review) is the author/funder, who has granted medRxiv a license to display the preprint in perpetuity.

It is made available under a CC-BY-NC 4.0 International license.

Six studies including 18640 patients were included in the final analysis. There was no difference in overall complications within or after 72 hours cholecystectomy group, but mortality and biliary complications were significantly high in the less than 72 hours group $(p=0.05$ and 0.0002 respectively). There was no difference in mortality, overall complication, biliary tract complications in less than 1 week versus more than 1 week and less than 10 days versus more than 10 days group. Overall complications were significantly less in the less than 2 weeks group compared to the more than 2 weeks group. There was no difference in mortality and biliary tract complications between less than 2 weeks and more than 2 weeks group. Overall complication rate (risk ratio $0.67, \mathrm{p}<0.0001$ ), postoperative mortality (risk ratio $0.46, \mathrm{p}=0.003$ ), bile duct injury (risk ratio $0.62, \mathrm{p}=0.01$ ) was significantly less in earlier than 4-week group. Hospital stay was not significantly different between less than 4 weeks versus more than 4 weeks group. (Mean difference $=-2.74, \mathrm{p}=0.12$ ). Ove all complication rates were significantly more in less than 8 weeks group. (Risk ratio $1.07, \mathrm{p}=0.01$ ). Hospital stay was significantly less in less than 8 weeks group. (Mean difference 0.87, $\mathrm{p}=0.01$ ).

\section{Conclusion:}

Early cholecystectomy preferably within 4 weeks after percutaneous cholecystostomy is preferable over late cholecystectomy.

\section{Introduction:}

Acute cholecystitis is a very common presentation in surgical practice. Laparoscopic cholecystectomy is the gold standard surgical procedure to treat acute cholecystitis. Earlier it was believed that acute cholecystitis should be treated conservatively initially and then interval 
medRxiv preprint doi: https://doi.org/10.1101/2021.06.06.21258426; this version posted June 12, 2021. The copyright holder for this preprint (which was not certified by peer review) is the author/funder, who has granted medRxiv a license to display the preprint in perpetuity.

It is made available under a CC-BY-NC 4.0 International license .

cholecystectomy should be offered, but now early cholecystectomy preferably within 72 hours of presentation is preferred over interval cholecystectomy. [1,2,3]

Percutaneous cholecystostomy is now emerging as a bridge to surgery to control sepsis when a patient is too sick for surgery or when a patient is unfit for surgery or has a high risk of postoperative mortality. [4] In the case of acute calculous cholecystitis, cholecystectomy is needed after a patient is stabilized with percutaneous cholecystostomy. However, the timing of subsequent cholecystectomy remains controversial, and very little data is available regarding that.

\section{Aim:}

This systematic review and meta-analysis aimed to evaluate outcomes of early versus late cholecystectomy after percutaneous cholecystectomy.

\section{Methods:}

The study was conducted according to the PRISMA 2020 statement and MOOSE guidelines. $[5,6]$.

\section{Study selection:}

We conducted a literature search as described by Gossen et al. [7] PubMed, Cochrane Library, Embase, Google Scholar, Web of Science with keywords and "MESH" terms like "percutaneous cholecystostomy", "Cholecystectomy", "Timing of cholecystectomy", "early versus late cholecystostomy", "cholecystectomy AND cholecystostomy", "cholecystectomy after cholecystostomy". Two independent authors extracted the data (B.V. and H.P.) Discussions and mutual understanding resolved any disagreements. 
medRxiv preprint doi: https://doi.org/10.1101/2021.06.06.21258426; this version posted June 12, 2021. The copyright holder for this preprint (which was not certified by peer review) is the author/funder, who has granted medRxiv a license to display the preprint in perpetuity.

It is made available under a CC-BY-NC 4.0 International license .

\section{Statistical analysis:}

The meta-analysis was conducted using Review Manager 5.4. Heterogeneity was measured using $\mathrm{Q}$ tests and $\mathrm{I} 2$, and $\mathrm{P}<.10$ was determined as significant, the random-effects model was used. The odds ratio (OR) was calculated for dichotomous data, and weighted mean differences (WMD) were used for continuous variables. Both differences were presented with 95\% CI. For continuous variables, if data were presented with medians and ranges, then we calculated the means and standard deviations according to Hozo et al. [8]. If the study presented the median and interquartile range, the median was treated as the mean, and the interquartile ranges were calculated using 1.35 SDs, as described in the Cochrane handbook. [9]

\section{Risk of bias assessment:}

Cohort studies were assessed for bias using the Newcastle -Ottawa Scale. [10]. It was decided to assess randomized trials based on the Cochrane Handbook.[9]. However, in the final analysis, we could not find any randomized clinical trials fulfilling our inclusion criteria so the Newcastle Ottawa Scale was used. We evaluated publication bias by funnel plots. We defined mortality as postoperative 90 days mortality. We evaluated various periods of cholecystectomy after percutaneous cholecystectomy like within 72 hours, within 7 days, within 10 days, within two weeks, within 4 weeks, or within or after 8 weeks.

\section{Inclusion criteria:}

- Studies that evaluated early vs late cholecystectomy after percutaneous cholecystostomy.

- Full-text articles.

- Conference abstracts that contain adequate information.

\section{Exclusion criteria:}


medRxiv preprint doi: https://doi.org/10.1101/2021.06.06.21258426; this version posted June 12, 2021. The copyright holder for this preprint (which was not certified by peer review) is the author/funder, who has granted medRxiv a license to display the preprint in perpetuity.

It is made available under a CC-BY-NC 4.0 International license.

- Studies which does not contain early vs late cholecystectomy after percutaneous cholecystostomy.

- Articles where full texts were not available.

- Conference abstracts without adequate details.

\section{Results:}

Six studies including 18640 patients were included in the final analysis. [11-17]. [Figure 1]. Characteristics of the included studies are described in table 1. The risk of bias summary is shown in figure 2.

\section{Cholecystectomy within 72 hours of percutaneous cholecystostomy: [Figure 3]}

Two studies consisting of 9323 patients evaluated cholecystectomy within or after 72 hours of initial percutaneous cholecystostomy. [11,12]. There was no difference in overall complications and conversion to open between the groups. $(\mathrm{p}=0.43, \mathrm{p}=0.41$ respectively $)$. Biliary complications were significantly less in cholecystectomy within 72 hours. (Risk ratio $0.36, \mathrm{p}=$ 0.0002). 90 days mortality was significantly higher in the early cholecystectomy group. (Risk ratio $1.8, \mathrm{p}=0.05)$.

\section{Cholecystectomy within 1 week of percutaneous cholecystostomy: [Figure 4]}

One study consisting of 9256 patients [12] compared cholecystectomy earlier than one week after percutaneous cholecystostomy to cholecystectomy after one week. There was no significant 
medRxiv preprint doi: https://doi.org/10.1101/2021.06.06.21258426; this version posted June 12, 2021. The copyright holder for this preprint (which was not certified by peer review) is the author/funder, who has granted medRxiv a license to display the preprint in perpetuity. It is made available under a CC-BY-NC 4.0 International license.

difference between overall complications, 90 days mortality, and biliary complications. $(\mathrm{p}=$ 0.23,0.85.0.27 respectively).

\section{Cholecystectomy within 10 days of percutaneous cholecystostomy: [Figure 5]}

One study with 74 patients [13] evaluated cholecystectomy within or after 10 days of percutaneous cholecystostomy. There was no difference in conversion to open, overall complications, and bile duct injury between cholecystectomy within or after 10 days. $(\mathrm{p}=0.43,0.36 .0 .36$ respectively).

\section{Cholecystectomy within 2 weeks of percutaneous cholecystostomy: [Figure 6]}

One study consisting of 9256 patients [12] compared cholecystectomy earlier than two weeks after percutaneous cholecystostomy to cholecystectomy after two weeks. Overall complications were significantly less in cholecystectomy earlier than two weeks. ( $p=0.02$, Risk ratio 0.85$)$. There was no difference in 90 days mortality and biliary complications. ( $\mathrm{p}=0.48,0.34$ respectively)

\section{Cholecystectomy within 4 weeks of percutaneous cholecystostomy: [Figure 7]}

Two studies consisting of 9356 patients evaluated cholecystectomy within or after 4 weeks of initial percutaneous cholecystostomy. $[12,14]$. There was no difference in conversion to open in both groups. $(\mathrm{p}=0.13)$. Overall complications were significantly less in the within 4 weeks cholecystectomy group. (risk ratio 0.67, p <0.00001), 90 days mortality was also significantly less in cholecystectomy within 4 weeks. (Risk ratio $0.46, \mathrm{p}=0.003$ ). Biliary tract complications were significantly low in the early cholecystectomy group. (Risk ratio $0.62, \mathrm{p}=0.01$ ). There was no difference in hospital stay between the two groups. $(\mathrm{p}=0.12)$ 
medRxiv preprint doi: https://doi.org/10.1101/2021.06.06.21258426; this version posted June 12, 2021. The copyright holder for this preprint (which was not certified by peer review) is the author/funder, who has granted medRxiv a license to display the preprint in perpetuity.

It is made available under a CC-BY-NC 4.0 International license.

\section{Cholecystectomy within 8 weeks of percutaneous cholecystostomy: [Figure 8]}

Two studies consisting of 9143 patients evaluated cholecystectomy within or after 4 weeks of initial percutaneous cholecystostomy. $[15,16]$. There was no difference in conversion to open in both groups. $(\mathrm{p}=0.77)$. Overall complications were significantly more in within 8 weeks cholecystectomy group. (risk ratio 1.07, p =0.01). There was no difference in 90 days mortality between the groups. $(\mathrm{p}=0.57)$. Hospital stay was significantly more in cholecystectomy less than 8 weeks group. (mean difference $0.87, \mathrm{p}=0.01$ ). There was no difference in risk of subtotal cholecystectomy between groups. $(\mathrm{p}=0.75)$.

Heterogeneity was not significant in the majority of analysis as shown in forest plots, in some of the heterogeneity analysis was not possible as very few studies were there. Publication bias was not significant.

\section{Discussion:}

Percutaneous cholecystostomy is increasingly being used for definitive treatment of acalculous cholecystitis and as a bridge to surgery in case of calculous cholecystitis in a patient with a high risk of surgery due to comorbidities or sometimes ongoing septic shock. [16-20]. There is ongoing controversy about the optimal time of cholecystectomy after percutaneous cholecystostomy in the case of calculous cholecystectomy.

In this systematic review and meta-analysis, we tried to evaluate the optimal timing of cholecystectomy after percutaneous cholecystostomy in the case of calculous cholecystitis.. We evaluated conversion to open, overall complications after cholecystectomy, biliary complications, 90-day mortality, hospital stay after cholecystectomy performed in various time frames after cholecystostomy based on available literature. 
medRxiv preprint doi: https://doi.org/10.1101/2021.06.06.21258426; this version posted June 12, 2021. The copyright holder for this preprint (which was not certified by peer review) is the author/funder, who has granted medRxiv a license to display the preprint in perpetuity.

It is made available under a CC-BY-NC 4.0 International license .

After a systematic search described in methodology and removing duplicates, we found six articles [11-17], which evaluated the timing of cholecystectomy after percutaneous cholecystostomy. There was a lack of uniformity about the timing of cholecystectomy after percutaneous cholecystostomy in the available literature, so we evaluated different time frames in our meta-analysis.

As per findings of the meta-analysis, there was no increase in conversion to open, and overall complications of cholecystectomy are performed within 72 hours of percutaneous cholecystostomy, biliary complications were lesser if cholecystectomy is performed within 72 hours of percutaneous cholecystostomy. However, 90 days mortality was slightly higher $(\mathrm{p}=0.05)$ if cholecystectomy is performed within 72 hours but we are not sure this is due to cholecystectomy or due to underlying conditions. [figure 3].

We found no increase in mortality, overall complications, biliary complications, and conversion to open if cholecystectomy is performed within 7 and 10 days after percutaneous cholecystostomy. [figure 4,5]. Only one study [12] evaluated cholecystectomy within or after two weeks of percutaneous cholecystostomy, which also showed early cholecystectomy reduced overall complications without increasing mortality and biliary complications. [figure 6].

Maximum benefit is observed as per our meta-analysis when cholecystectomy is performed within 4 weeks of percutaneous cholecystostomy. It reduced overall complications, biliary complications, 90 days mortality, hospital stay without increasing conversion to open cholecystectomy. [figure 7].

In studies comparing cholecystectomy within or after 8 weeks of percutaneous cholecystostomy $[15,16]$, overall complications and hospital stay were significantly more in cholecystectomy in 
medRxiv preprint doi: https://doi.org/10.1101/2021.06.06.21258426; this version posted June 12, 2021. The copyright holder for this preprint (which was not certified by peer review) is the author/funder, who has granted medRxiv a license to display the preprint in perpetuity. It is made available under a CC-BY-NC 4.0 International license .

less than 8 weeks compared to cholecystectomy in more than 8 weeks. There was no difference in conversion to open, 90-day mortality and need for subtotal cholecystectomy between the groups.

Based, on these findings, it seems that less than 4 weeks is the ideal time for cholecystectomy after percutaneous cholecystostomy for calculus cholecystitis.

There were certain limitations in our meta-analysis, first, we could include only a limited number of studies as there is still a limited number of studies done in this research question. Three studies $[12,15,16]$ had the majority of patients and other studies included a very limited number of patients and hence results can be skewed by the weight given to those three studies during various analyses. Also, the time duration of cholecystectomy after cholecystostomy varied widely across the studies. So, we had to analyze various time frames.

To our knowledge, this is the first meta-analysis evaluating the optimal time duration of cholecystectomy after percutaneous cholecystostomy. Also, analysis across various time frames confirmed that earlier cholecystectomy is not harmful as it was thought. The ideal time duration from our analysis seems earlier than 4 weeks, most probably 1-4 weeks. The most favorable findings are fewer overall and biliary complications in early cholecystectomy without increased need to convert to open cholecystectomy. However, still, studies with a larger number of patients or randomized control trials are needed to confirm our findings.

In conclusion, early cholecystectomy preferably within 4 weeks after cholecystostomy is safe and probably beneficial to the patients. However, further studies are still needed to confirm the findings of this meta-analysis.

\section{References:}


medRxiv preprint doi: https://doi.org/10.1101/2021.06.06.21258426; this version posted June 12, 2021. The copyright holder for this preprint (which was not certified by peer review) is the author/funder, who has granted medRxiv a license to display the preprint in perpetuity. It is made available under a CC-BY-NC 4.0 International license .

1. Yamashita Y, Takada T, Hirata K. A survey of the timing and approach to the surgical management of patients with acute cholecystitis in Japanese hospitals. J Hepatobiliary Pancreat Surg 2006;13:409-415.

2. Zucker KA, Flowers JL, Bailey RW, Graham SM, Buell J, Imbembo AL. Laparoscopic management of acute cholecystitis. Am J Surg 1993;165:508-514.

3. Knight JS, Mercer SJ, Somers SS, Walters AM, Sadek SA, Toh SK. Timing of urgent laparoscopic cholecystectomy does not influence conversion rate. $\mathrm{Br} \mathrm{J}$ Surg 2004;91:601-604.

4. Elsharif M, Forouzanfar A, Oaikhinan K, Khetan N. Percutaneous cholecystostomy... why, when, what next? A systematic review of past decade. Ann R Coll Surg Engl. 2018 Oct 5;100(8):1-14.

5. Page MJ, McKenzie JE, Bossuyt PM, et al. The PRISMA 2020 statement: an updated guideline for reporting systematic reviews. BMJ. 2021;372:n71. Published 2021 Mar 29.

6. Stroup DF, Berlin JA, Morton SC, et al. Meta-analysis of observational studies in epidemiology: a proposal for reporting. Meta-analysis Of Observational Studies in Epidemiology (MOOSE) group. JAMA. 2000;283(15):2008-2012.

7. . Goossen K, Tenckhoff S, Probst P, et al. Optimal literature search for systematic reviews in surgery. Langenbecks Arch Surg. 2018;403(1): 119-129.

8. Hozo SP, Djulbegovic B, Hozo I. Estimating the mean and variance from the median, range, and the size of a sample. BMC Med Res Methodol. 2005;5:13.

9. Higgins JP, Altman DG, Gøtzsche PC, et al. The cochrane collaboration's tool for assessing risk of bias in randomised trials. BMJ. 2011; 343:d5928. 
medRxiv preprint doi: https://doi.org/10.1101/2021.06.06.21258426; this version posted June 12, 2021. The copyright holder for this preprint (which was not certified by peer review) is the author/funder, who has granted medRxiv a license to display the preprint in perpetuity. It is made available under a CC-BY-NC 4.0 International license .

10. Wells G, Shea B, O'Connell D, et al. The Newcastle-Ottawa scale (NOS) for assessing the quality of nonrandomized studies in metaanalyses. 2016.

11. Han IW, Jang JY, Kang MJ, Lee KB, Lee SE, Kim SW. Early versus delayed laparoscopic cholecystectomy after percutaneous transhepatic gallbladder drainage. $J$ Hepatobiliary Pancreat Sci. 2012;19(2):187-193.

12. Sakamoto T, Fujiogi M, Matsui H, Fushimi K, Yasunaga H. Timing of cholecystectomy after percutaneous transhepatic gallbladder drainage for acute cholecystitis: a nationwide inpatient database study. HPB (Oxford). 2020;22(6):920-926.

13. Jung WH, Park DE. Timing of Cholecystectomy after Percutaneous Cholecystostomy for Acute Cholecystitis. Korean J Gastroenterol. 2015;66(4):209-214.

14. Lyu Y, Li T, Wang B, Cheng Y. Early laparoscopic cholecystectomy after percutaneous transhepatic gallbladder drainage for acute cholecystitis. Sci Rep. 2021;11(1):2516.

15. Woodward SG, Rios-Diaz AJ, Zheng R, et al. Finding the Most Favorable Timing for Cholecystectomy after Percutaneous Cholecystostomy Tube Placement: An Analysis of Institutional and National Data. J Am Coll Surg. 2021;232(1):55-64.

16. Altieri MS, Yang J, Yin D, Brunt LM, Talamini MA, Pryor AD. Early cholecystectomy ( $\leq \square 8$ weeks) following percutaneous cholecystostomy tube placement is associated with higher morbidity. Surg Endosc. 2020;34(7):3057-3063.

17. Griniatsos J, Petrou A, Pappas P et al. Percutaneous cholecystostomy without interval cholecystectomy as definitive treatment of acute cholecystitis in elderly and critically ill patients. South Med J 2018; 101: 586-590. 
medRxiv preprint doi: https://doi.org/10.1101/2021.06.06.21258426; this version posted June 12, 2021. The copyright holder for this preprint (which was not certified by peer review) is the author/funder, who has granted medRxiv a license to display the preprint in perpetuity.

It is made available under a CC-BY-NC 4.0 International license.

18. Horn T, Christensen SD, Kirkegard J et al. Percutaneous cholecystostomy is an effective treatment option for acute calculous cholecystitis: a 10-year experience. HPB (Oxford) $2015 ; 17: 326-331$.

19. Hsieh YC, Chen CK, Su CW et al. Outcome after percutaneous cholecystostomy for acute cholecystitis: a single-center experience. J Gastrointest Surg 2012;16: 1,860-1,868.

20. Jang WS, Lim JU, Joo KR et al. Outcome of conservative percutaneous cholecystostomy in high-risk patients with acute cholecystitis and risk factors leading to surgery. Surg Endosc 2-15; 29: 2,359-2,364.

\begin{tabular}{|c|c|c|c|c|}
\hline Study & Published year & Type of study & $\begin{array}{l}\text { Definition of } \\
\text { early } \\
\text { cholecystectomy } \\
\text { post } \\
\text { percutaneous } \\
\text { cholecystostomy }\end{array}$ & Total patients \\
\hline Han et al.[11] & 2011 & $\begin{array}{l}\text { Retrospective } \\
\text { cohort }\end{array}$ & Within 72 hours & 67 \\
\hline Jung et al.[13]. & 2015 & $\begin{array}{l}\text { Retrospective } \\
\text { cohort }\end{array}$ & $\begin{array}{l}\text { Within } \quad 7-10 \\
\text { days }\end{array}$ & 74 \\
\hline
\end{tabular}


medRxiv preprint doi: https://doi.org/10.1101/2021.06.06.21258426; this version posted June 12, 2021. The copyright holder for this preprint (which was not certified by peer review) is the author/funder, who has granted medRxiv a license to display the preprint in perpetuity.

It is made available under a CC-BY-NC 4.0 International license .

\begin{tabular}{|c|c|c|c|c|}
\hline Lyu et al.[14] & 2021 & $\begin{array}{l}\text { Retrospective } \\
\text { cohort }\end{array}$ & 4 weeks & 100 \\
\hline $\begin{array}{l}\text { Sakamoto et } \\
\text { al[12]. }\end{array}$ & 2019 & $\begin{array}{l}\text { Retrospective } \\
\text { cohort }\end{array}$ & 4 weeks & 9256 \\
\hline $\begin{array}{l}\text { Alteri et } \\
\text { al.[16] }\end{array}$ & 2019 & $\begin{array}{l}\text { Retrospective } \\
\text { cohort }\end{array}$ & 8 weeks & 2998 \\
\hline $\begin{array}{l}\text { Woodward et } \\
\text { al.[15] }\end{array}$ & 2020 & $\begin{array}{l}\text { Retrospective } \\
\text { cohort }\end{array}$ & 8 weeks & 6145 \\
\hline
\end{tabular}

\section{Table 1. Study Characteristics.}

\section{Identification of studies via databases and registers}

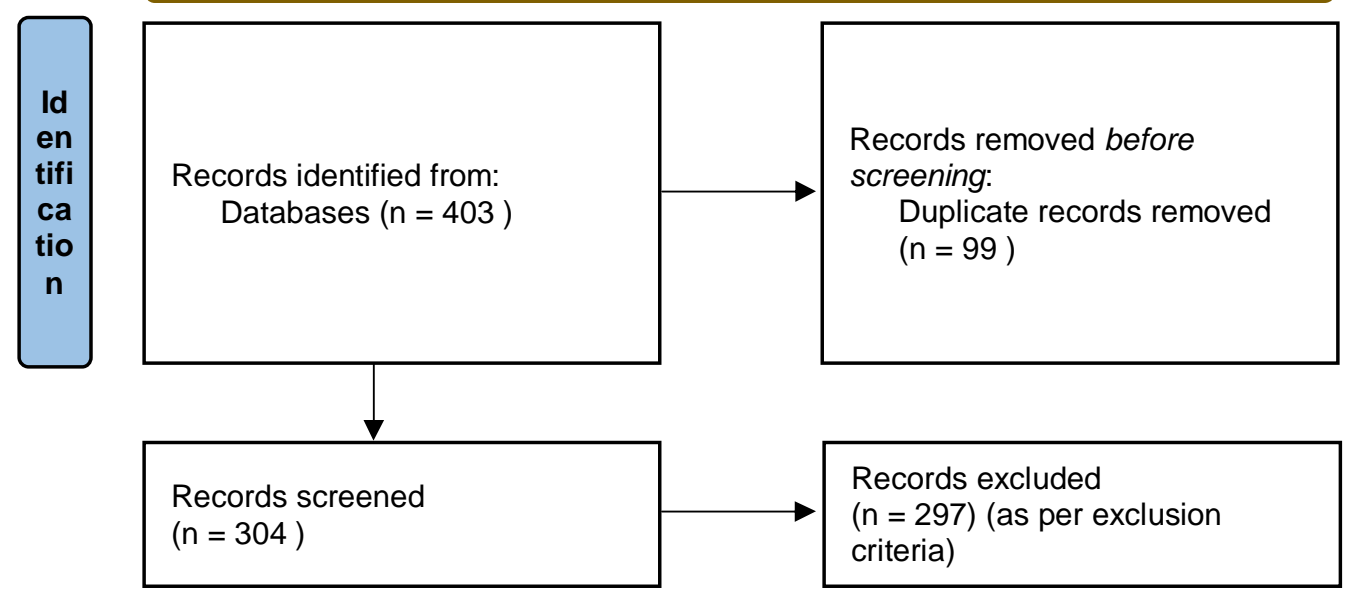


medRxiv preprint doi: https://doi.org/10.1101/2021.06.06.21258426; this version posted June 12, 2021. The copyright holder for this preprint (which was not certified by peer review) is the author/funder, who has granted medRxiv a license to display the preprint in perpetuity.

$$
\text { It is made available under a CC-BY-NC } 4.0 \text { International license. }
$$
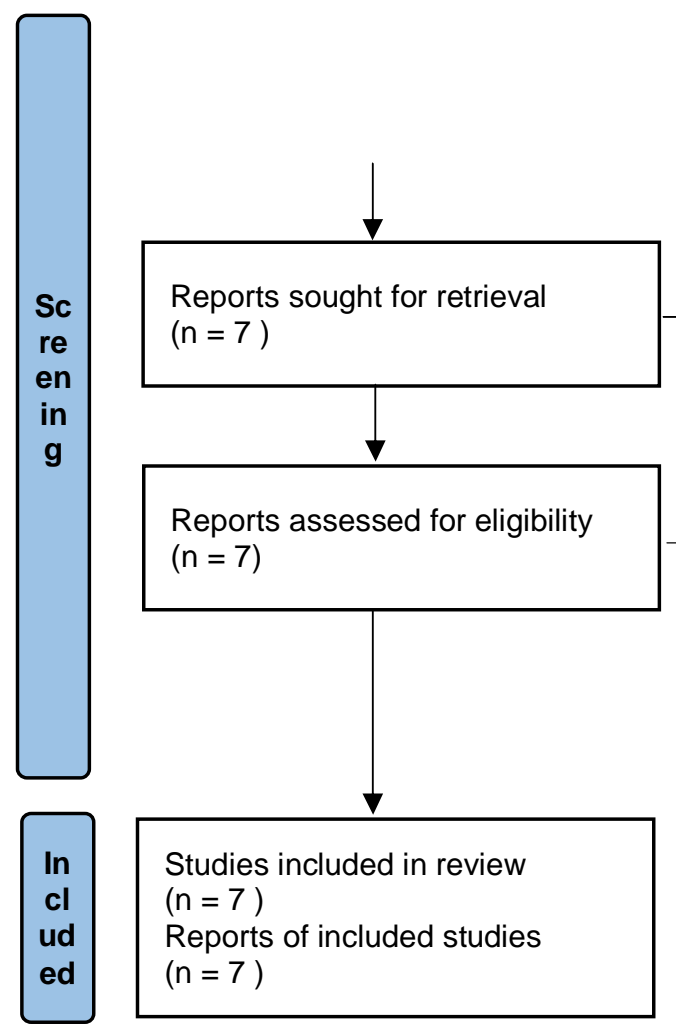

From: Page MJ, McKenzie JE, Bossuyt PM, Boutron I, Hoffmann TC, Mulrow CD, et al. The PRISMA 2020 statement: an updated guideline for reporting systematic reviews. BMJ 2021;372:n71. doi: 10.1136/bmj.n71

\section{Figure 1: Prisma flow chart.}


medRxiv preprint doi: https://doi.org/10.1101/2021.06.06.21258426; this version posted June 12, 2021. The copyright holder for this preprint (which was not certified by peer review) is the author/funder, who has granted medRxiv a license to display the preprint in perpetuity.

It is made available under a CC-BY-NC 4.0 International license .

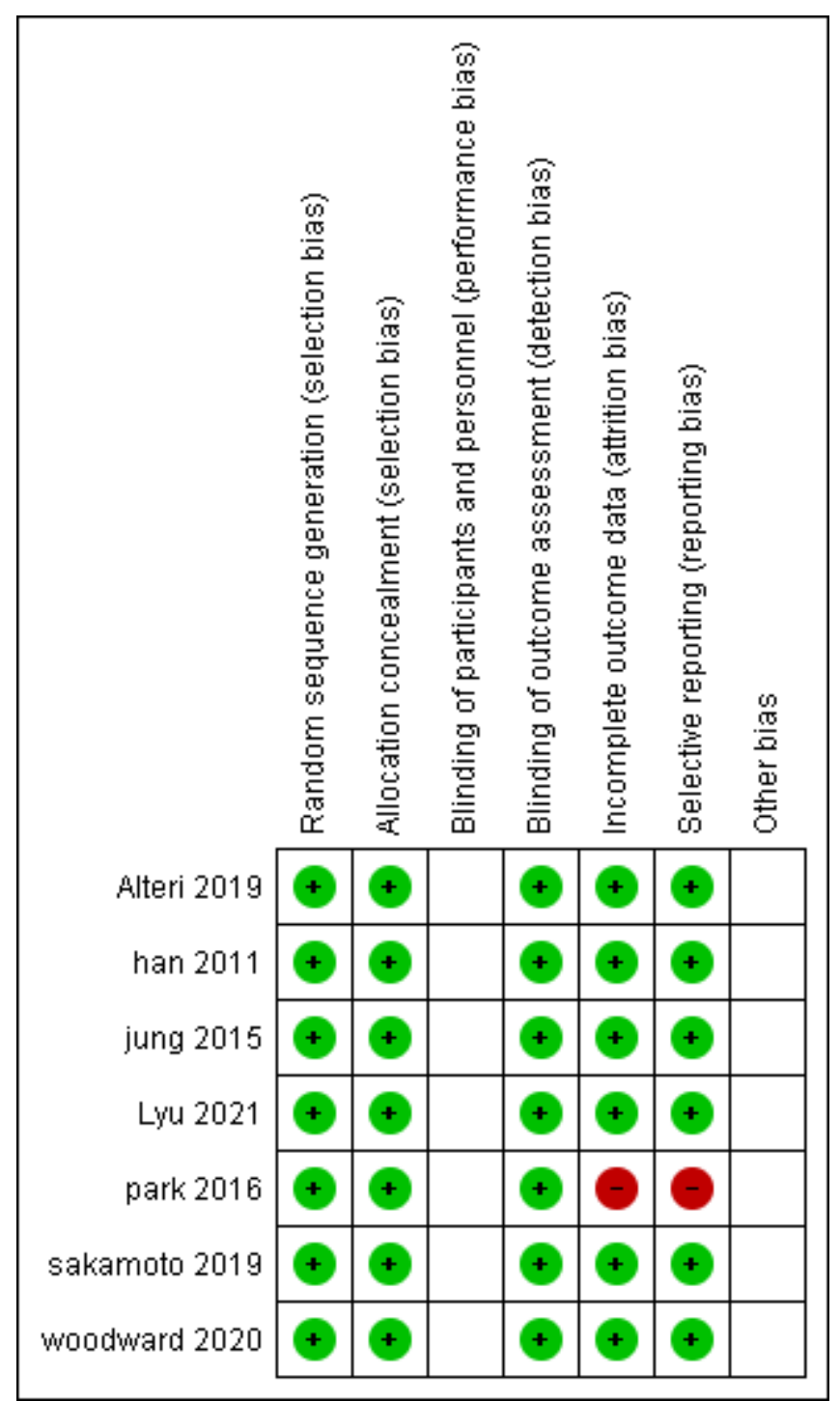

Figure 2. Risk of bias summary ( green denotes low risk of bias, red high risk of bias and empty spaces swhos unclear bias) 
medRxiv preprint doi: https://doi.org/10.1101/2021.06.06.21258426; this version posted June 12, 2021. The copyright holder for this preprint (which was not certified by peer review) is the author/funder, who has granted medRxiv a license to display the preprint in perpetuity.

It is made available under a CC-BY-NC 4.0 International license.

\begin{tabular}{|c|c|c|c|c|c|c|c|c|c|c|}
\hline Study or Subgroup & \multicolumn{2}{|c|}{ early } & \multicolumn{2}{|l|}{ late } & Weight & $\begin{array}{c}\text { Risk Ratio } \\
\text { M-H, Random, } 95 \% \mathrm{Cl}\end{array}$ & \multicolumn{4}{|c|}{$\begin{array}{c}\text { Risk Ratio } \\
\text { M-H, Random, } 95 \% \mathrm{Cl}\end{array}$} \\
\hline han 2011 & 0 & 21 & 3 & 46 & $100.0 \%$ & $0.31[0.02,5.66]$ & & & & \\
\hline Total (95\% Cl) & & 21 & & 46 & $100.0 \%$ & $0.31[0.02,5.66]$ & & & & \\
\hline Total events & 0 & & 3 & & & & & & & \\
\hline $\begin{array}{l}\text { Heterogeneity: Not a } \\
\text { Test for overall effect }\end{array}$ & $\begin{array}{l}\text { plicable } \\
Z=0.80\end{array}$ & $(P=0.4$ & & & & & 0.01 & $\begin{array}{c}1 \\
0.1 \\
\text { Favours [early] }\end{array}$ & $\begin{array}{cc} & 10 \\
\text { Favours [late] }\end{array}$ & 100 \\
\hline
\end{tabular}

Figure 3(a) Conversion to open.

\begin{tabular}{|c|c|c|c|c|c|c|c|c|c|c|}
\hline Study or Subgroup & \multicolumn{2}{|c|}{ early } & \multicolumn{2}{|c|}{ late } & Weight & \multicolumn{2}{|l|}{ Risk Ratio } & \multicolumn{2}{|c|}{$\begin{array}{c}\text { Risk Ratio } \\
\text { M-H, Random, } 95 \% \mathrm{Cl}\end{array}$} & \\
\hline han 2011 & 4 & 21 & 2 & 46 & $32.8 \%$ & $4.38[0.87,22.07]$ & & & $=$ & \\
\hline sakamoto 2019 & 75 & 864 & 668 & 8392 & $67.2 \%$ & $1.09[0.87,1.37]$ & & & & \\
\hline Total $(95 \% \mathrm{Cl})$ & & 885 & & 8438 & $100.0 \%$ & $1.72[0.48,6.18]$ & & & & \\
\hline Total events & 79 & & 670 & & & & & & & \\
\hline $\begin{array}{l}\text { Heterogeneity: Tau }{ }^{2} \\
\text { Test for overall effec }\end{array}$ & $\begin{array}{l}0.62 ; \mathrm{Chi}^{-} \\
\mathrm{Z}=0.83(\end{array}$ & $\begin{array}{l}=2.7 \\
P=0.4\end{array}$ & $\begin{array}{l}9, \mathrm{df}=1( \\
11)\end{array}$ & $P=0.1$ & $0 ; I^{2}=64$ & & 0.01 & $\begin{array}{c}1 \\
0.1 \\
\text { Favours [early] }\end{array}$ & \begin{tabular}{|c|}
1 \\
10 \\
Favours [late]
\end{tabular} & 100 \\
\hline
\end{tabular}

Figure 3 (b) Over all complications.

\begin{tabular}{|c|c|c|c|c|c|c|c|c|c|c|}
\hline \multirow{3}{*}{$\begin{array}{l}\text { Study or Subgroup } \\
\text { han } 2011 \\
\text { sakamoto } 2019\end{array}$} & \multirow{2}{*}{$\begin{array}{r}\begin{array}{r}\text { early } \\
\text { Events }\end{array} \\
0\end{array}$} & \multirow{2}{*}{$\begin{array}{r}\text { Total } \\
21\end{array}$} & $\begin{array}{l}\text { late } \\
\text { Events }\end{array}$ & Total & Weight & \multirow{2}{*}{$\begin{array}{c}\text { Risk Ratio } \\
\text { M-H, Random, } 95 \% \mathrm{Cl}\end{array}$} & \multicolumn{4}{|c|}{$\begin{array}{c}\text { Risk Ratio } \\
\text { M-H, Random, } 95 \% \mathrm{Cl}\end{array}$} \\
\hline & & & 0 & 46 & & & & & & \\
\hline & 14 & 864 & 378 & 8392 & $100.0 \%$ & $0.36[0.21,0.61]$ & & & & \\
\hline Total $(95 \% \mathrm{Cl})$ & & 885 & & 8438 & $100.0 \%$ & $0.36[0.21,0.61]$ & & & & \\
\hline Total events & 14 & & 378 & & & & & & & \\
\hline $\begin{array}{l}\text { Heterogeneity: Not a } \\
\text { Test for overall effect }\end{array}$ & $\begin{array}{l}\text { plicable } \\
Z=3.79\end{array}$ & $P=0.0$ & 0002) & & & & 0.01 & $\begin{array}{c}0.1 \\
\text { Favours [early] }\end{array}$ & $\begin{array}{r}10 \\
10 \\
\text { Favours [late] }\end{array}$ & 100 \\
\hline
\end{tabular}

Figure 3 (c) Biliary tract complications.

\begin{tabular}{|c|c|c|c|c|c|c|c|c|c|c|}
\hline Study or Subgroup & $\begin{array}{l}\text { earl } \\
\text { Events }\end{array}$ & Total & $\begin{array}{l}\text { late } \\
\text { Events }\end{array}$ & Total & Weight & $\begin{array}{c}\text { Risk Ratio } \\
\text { M-H, Random, } 95 \% \mathrm{Cl}\end{array}$ & & $\begin{array}{r}\text { Risk } \\
\text { M-H, Rand }\end{array}$ & $\begin{array}{l}\text { Ratio } \\
\text { om, } 95 \% \mathrm{Cl}\end{array}$ & \\
\hline sakamoto 2019 & 13 & 864 & 70 & 8392 & $100.0 \%$ & $1.80[1.00,3.25]$ & & & & \\
\hline Total $(95 \% \mathrm{Cl})$ & & 864 & & 8392 & $100.0 \%$ & $1.80[1.00,3.25]$ & & & & \\
\hline Total events & 13 & & 70 & & & & & & & \\
\hline \multicolumn{7}{|c|}{$\begin{array}{l}\text { Heterogeneity: Not applicable } \\
\text { Test for overall effect: } Z=1.97(P=0.05)\end{array}$} & 0.01 & $\begin{array}{l}0.1 \\
\text { Favours [early] }\end{array}$ & Favours [late] & 100 \\
\hline
\end{tabular}

Figure 3 (d) 90 days mortality.

Figure 3. Comparisons between cholecystectomy within or after 72 hours after percutaneous cholecystostomy. 
medRxiv preprint doi: https://doi.org/10.1101/2021.06.06.21258426; this version posted June 12, 2021. The copyright holder for this preprint (which was not certified by peer review) is the author/funder, who has granted medRxiv a license to display the preprint in perpetuity.

\section{It is made available under a CC-BY-NC 4.0 International license .}

\begin{tabular}{|c|c|c|c|c|c|c|c|c|c|c|}
\hline Study or Subgroup & \multicolumn{2}{|c|}{ Early } & \multicolumn{2}{|l|}{ late } & Weight & Risk Ratio & \multicolumn{4}{|c|}{$\begin{array}{c}\text { Risk Ratio } \\
\text { M-H, Random, } 95 \% \mathrm{Cl}\end{array}$} \\
\hline sakamoto 2019 & 168 & 2260 & 575 & 6996 & $100.0 \%$ & $0.90[0.77,1.07]$ & & & & \\
\hline Total (95\% Cl) & & 2260 & & 6996 & $100.0 \%$ & $0.90[0.77,1.07]$ & & & & \\
\hline Total events & 168 & & 575 & & & & & & & \\
\hline $\begin{array}{l}\text { Heterogeneity: Not a } \\
\text { Test for overall effec }\end{array}$ & $\begin{array}{l}\text { plicable } \\
z=1.19\end{array}$ & & & & & & 0.01 & $\begin{array}{c}0.1 \\
\text { Favours [early] }\end{array}$ & $\begin{array}{c}10 \\
\text { Favours [late] }\end{array}$ & 100 \\
\hline
\end{tabular}

Figure 4 (a) overall complications cholecystectomy within or after 7 days

\begin{tabular}{|c|c|c|c|c|c|c|c|c|c|}
\hline Study or Subgroup & $\begin{array}{l}\text { earl } \\
\text { Events }\end{array}$ & Total & $\begin{array}{l}\text { late } \\
\text { Events }\end{array}$ & Total & Weight & $\begin{array}{c}\text { Risk Ratio } \\
\text { M-H, Random, } 95 \% \mathrm{Cl}\end{array}$ & & $\begin{array}{c}\text { Risk Ratio } \\
\text { M-H, Random, } 95 \% \mathrm{Cl}\end{array}$ & \\
\hline sakamoto 2019 & 21 & 2260 & 62 & 6996 & $100.0 \%$ & $1.05[0.64,1.72]$ & & & \\
\hline Total $(95 \% \mathrm{Cl})$ & & 2260 & & 6996 & $100.0 \%$ & $1.05[0.64,1.72]$ & & & \\
\hline Total events & 21 & & 62 & & & & & & \\
\hline \multicolumn{6}{|c|}{$\begin{array}{l}\text { Heterogeneity: Not applicable } \\
\text { Test for overall effect: } Z=0.19(P=0.85)\end{array}$} & & 0.01 & $\begin{array}{ccc}0.1 & 1 & 10 \\
\text { Favours [early] } & \text { Favours [late] }\end{array}$ & 100 \\
\hline
\end{tabular}

Figure 4 (b) Mortality cholecystectomy within or after 7 days.

\begin{tabular}{|c|c|c|c|c|c|c|c|c|c|c|}
\hline Study or Subgroup & \multicolumn{2}{|c|}{ Early } & \multicolumn{2}{|l|}{ late } & Weight & $\begin{array}{c}\text { Risk Ratio } \\
\text { M-H, Random, } 95 \% \text { Cl }\end{array}$ & \multicolumn{4}{|c|}{$\begin{array}{c}\text { Risk Ratio } \\
\text { M-H, Random, } 95 \% \mathrm{Cl}\end{array}$} \\
\hline sakamoto 2019 & 168 & 2260 & 575 & 6996 & $100.0 \%$ & $0.90[0.77,1.07]$ & & & & \\
\hline Total (95\% Cl) & & 2260 & & 6996 & $100.0 \%$ & $0.90[0.77,1.07]$ & & & & \\
\hline Total events & 168 & & 575 & & & & & & & \\
\hline $\begin{array}{l}\text { Heterogeneity: Not a } \\
\text { Test for overall effect }\end{array}$ & $\begin{array}{l}\text { plicable } \\
Z=1.19\end{array}$ & $P=0.2$ & & & & & 0.01 & $\begin{array}{l}0.1 \\
\text { Favours [early] }\end{array}$ & $\begin{array}{cc}10 \\
\text { Favours [late] }\end{array}$ & 100 \\
\hline
\end{tabular}

Figure 4 (c) biliary complications cholecystectomy within or after 7 days.

Figure 4. Comparisons between cholecystectomy within or after 7 days after percutaneous cholecystostomy. 
medRxiv preprint doi: https://doi.org/10.1101/2021.06.06.21258426; this version posted June 12, 2021. The copyright holder for this preprint (which was not certified by peer review) is the author/funder, who has granted medRxiv a license to display the preprint in perpetuity.

It is made available under a CC-BY-NC 4.0 International license .

\begin{tabular}{|c|c|c|c|c|c|c|c|c|c|c|}
\hline \multirow[b]{2}{*}{ Study or Subgroup } & \multicolumn{2}{|c|}{ early cholecystectomy } & \multicolumn{2}{|c|}{ late cholecystectomy } & \multirow[b]{2}{*}{ Weight } & \multirow{2}{*}{$\begin{array}{c}\text { Risk Ratio } \\
\text { M-H, Random, } 95 \% \mathrm{Cl}\end{array}$} & \multirow{2}{*}{\multicolumn{4}{|c|}{ Risk Ratio }} \\
\hline & Events & Total & Events & Total & & & & & & \\
\hline jung 2015 & 10 & 30 & 11 & 44 & $100.0 \%$ & $1.33[0.65,2.74]$ & & & & \\
\hline Total $(95 \% \mathrm{Cl})$ & & 30 & & 44 & $100.0 \%$ & $1.33[0.65,2.74]$ & & & & \\
\hline Total events & 10 & & 11 & & & & & & & \\
\hline $\begin{array}{l}\text { Heterogeneity: Not a } \\
\text { Test for overall effect }\end{array}$ & $\begin{array}{l}\text { plicable } \\
Z=0.78(P=\end{array}$ & & & & & & 0.01 & $\begin{array}{c}1 \\
0.1 \\
\text { Fayours [Early] }\end{array}$ & Favours [la & 100 \\
\hline
\end{tabular}

Figure 5 (a) Conversion to open within or after 10 days

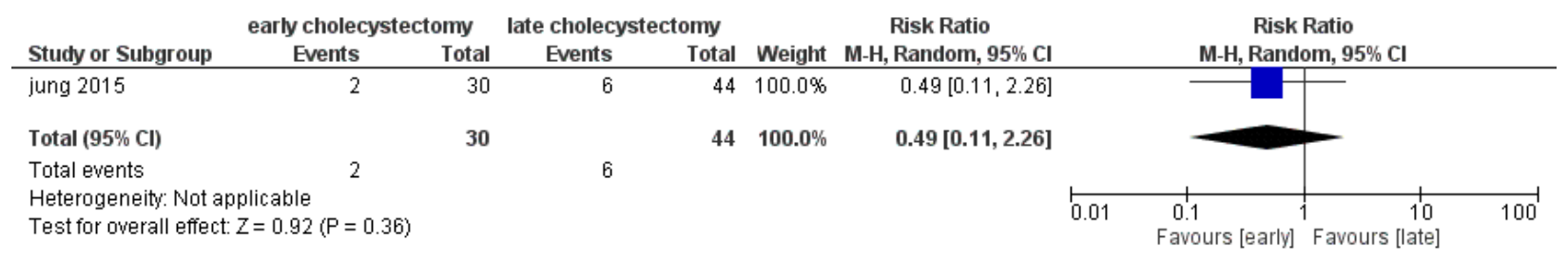

Figure 5 (b) overall complications cholecystectomy within or after 10 days

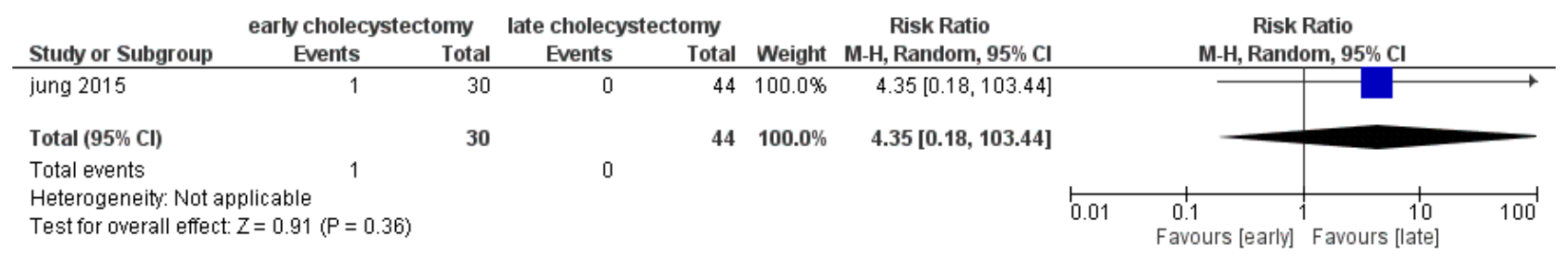

Figure 5 (c) bile duct injury within or after 10 days.

Figure 5. Comparisons between cholecystectomy within or after 10 days after percutaneous

cholecystostomy. 
medRxiv preprint doi: https://doi.org/10.1101/2021.06.06.21258426; this version posted June 12, 2021. The copyright holder for this preprint (which was not certified by peer review) is the author/funder, who has granted medRxiv a license to display the preprint in perpetuity.

\section{It is made available under a CC-BY-NC 4.0 International license .}

\begin{tabular}{|c|c|c|c|c|c|c|c|c|c|c|}
\hline Study or Subgroup & \multicolumn{2}{|c|}{ Early } & \multicolumn{2}{|l|}{ late } & Weight & \multicolumn{2}{|l|}{ Risk Ratio } & \multicolumn{2}{|c|}{$\begin{array}{c}\text { Risk Ratio } \\
\text { M-H, Random, } 95 \% \mathrm{Cl}\end{array}$} & \\
\hline sakamoto 2019 & 365 & 4932 & 378 & 4324 & $100.0 \%$ & $0.85[0.74,0.97]$ & & & & \\
\hline Total $(95 \% \mathrm{Cl})$ & & 4932 & & 4324 & $100.0 \%$ & $0.85[0.74,0.97]$ & & $\nabla$ & & \\
\hline Total events & 365 & & 378 & & & & & & & \\
\hline $\begin{array}{l}\text { Heterogeneity: Not a } \\
\text { Test for overall effect }\end{array}$ & $\begin{array}{l}\text { plicable } \\
Z=2.37\end{array}$ & $(P=0.0$ & & & & & 0.01 & $\begin{array}{c}1 \\
1 \\
\text { Favours [early] }\end{array}$ & $\begin{array}{c}10 \\
\text { Favours [late] }\end{array}$ & 100 \\
\hline
\end{tabular}

Figure 6 (a) overall complications cholecystectomy within or after 2 weeks.

\begin{tabular}{|c|c|c|c|c|c|c|c|c|c|c|}
\hline Study or Subgroup & \multicolumn{2}{|c|}{ Early } & \multicolumn{2}{|c|}{ late } & Weight & \multicolumn{2}{|l|}{ Risk Ratio } & \multicolumn{2}{|c|}{$\begin{array}{c}\text { Risk Ratio } \\
\text { M-H, Random, } 95 \% \mathrm{Cl}\end{array}$} & \\
\hline sakamoto 2019 & 41 & 4932 & 42 & 4324 & $100.0 \%$ & $0.86[0.56,1.31]$ & & & & \\
\hline Total $(95 \% \mathrm{Cl})$ & & 4932 & & 4324 & $100.0 \%$ & $0.86[0.56,1.31]$ & & & & \\
\hline Total events & 41 & & 42 & & & & & & & \\
\hline $\begin{array}{l}\text { Heterogeneity: Not a } \\
\text { Test for overall effec }\end{array}$ & $\begin{array}{l}\text { plicable } \\
Z=0.71\end{array}$ & $(P=0.4$ & & & & & 0.01 & $\begin{array}{c}1 \\
0.1 \\
\text { Favours [early] }\end{array}$ & $\begin{array}{c}10 \\
10 \\
\text { Favours [late] }\end{array}$ & 100 \\
\hline
\end{tabular}

Figure 6 (b) 90 days mortality cholecystectomy within or after 2 weeks.

\begin{tabular}{|c|c|c|c|c|c|c|c|c|c|c|}
\hline Study or Subgroup & \multicolumn{2}{|c|}{ Early } & $\begin{array}{l}\text { late } \\
\text { Events }\end{array}$ & Total & Weight & Risk Ratio & & \multicolumn{2}{|c|}{$\begin{array}{c}\text { Risk Ratio } \\
\text { M-H, Random, } 95 \% \mathrm{Cl}\end{array}$} & \\
\hline sakamoto 2019 & 86 & 4932 & 87 & 4324 & $100.0 \%$ & $0.87[0.65,1.16]$ & & & & \\
\hline Total $(95 \% \mathrm{Cl})$ & & 4932 & & 4324 & $100.0 \%$ & $0.87[0.65,1.16]$ & & & & \\
\hline Total events & 86 & & 87 & & & & & & & \\
\hline $\begin{array}{l}\text { Heterogeneity: Not a } \\
\text { Test for overall effect }\end{array}$ & $\begin{array}{l}\text { plicable } \\
Z=0.95(\end{array}$ & $P=0.3$ & & & & & 0.01 & $\begin{array}{l}0.1 \\
\text { Favours [early] }\end{array}$ & $\begin{array}{c}10 \\
\text { Favours [late] }\end{array}$ & 100 \\
\hline
\end{tabular}

Figure 6 (c) biliary complications cholecystectomy within or after 2 weeks.

Figure 6. Comparisons between cholecystectomy within or after 2 weeks after percutaneous cholecystostomy. 
medRxiv preprint doi: https://doi.org/10.1101/2021.06.06.21258426; this version posted June 12, 2021. The copyright holder for this preprint (which was not certified by peer review) is the author/funder, who has granted medRxiv a license to display the preprint in perpetuity.

It is made available under a CC-BY-NC 4.0 International license .

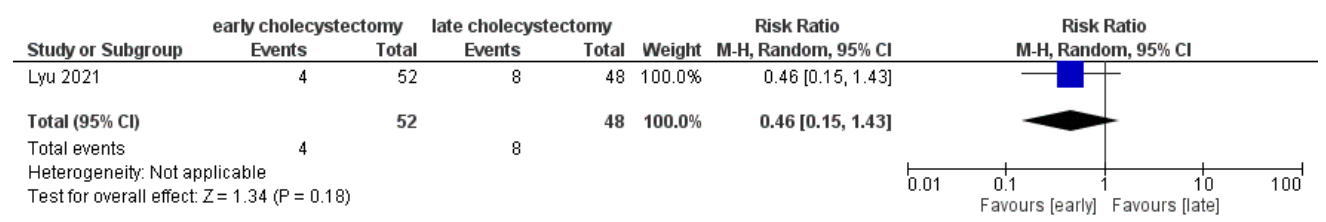

Figure 7 (a) Conversion to open cholecystectomy within or after 4 weeks.

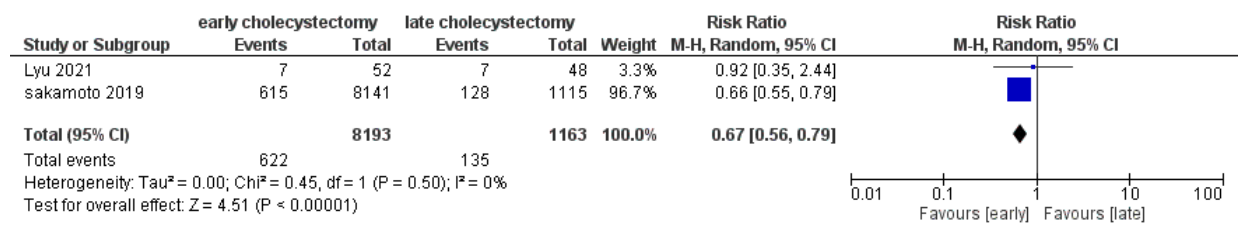

Figure 7 (b) Overall complications cholecystectomy within or after 4 weeks.

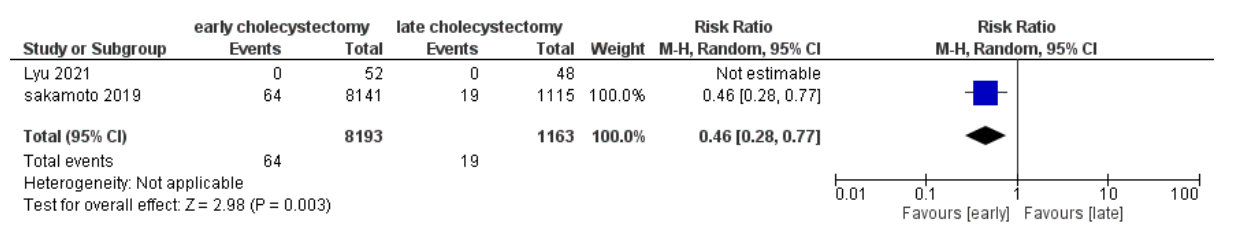

Figure 7 (c) 90 days mortality cholecystectomy within or after 4 weeks.

\begin{tabular}{|c|c|c|c|c|c|c|c|c|c|c|}
\hline \multirow[b]{2}{*}{ Study or Subgroup } & \multicolumn{2}{|c|}{ early cholecystectomy } & \multicolumn{2}{|c|}{ late cholecystectormy } & \multirow[b]{2}{*}{ Weight } & \multirow{2}{*}{$\begin{array}{c}\text { Risk Ratio } \\
\text { M-H, Random, } 95 \% \mathrm{Cl} \\
\end{array}$} & \multirow{2}{*}{\multicolumn{4}{|c|}{$\begin{array}{c}\text { Risk Ratio } \\
\text { M-H, Random, } 95 \% \mathrm{Cl}\end{array}$}} \\
\hline & Events & Total & Events & Total & & & & & & \\
\hline Lyu 2021 & 0 & 52 & 1 & 48 & $1.4 \%$ & $0.31[0.01,7.39]$ & & & & \\
\hline sakamoto 2019 & 142 & 8141 & 31 & 1115 & $98.6 \%$ & $0.63[0.43,0.92]$ & & & & \\
\hline Total $(95 \% \mathrm{Cl})$ & & 8193 & & 1163 & $100.0 \%$ & $0.62[0.42,0.91]$ & & & & \\
\hline Total events & 142 & & 32 & & & & & & & \\
\hline $\begin{array}{l}\text { Heterogeneity: Tauª } \\
\text { Test for overall effect }\end{array}$ & $\begin{array}{l}0.00 ; \mathrm{Ch}^{2}=0 . \\
Z=2.45(P=0\end{array}$ & $=1(P=$ & $=0.66) ;\left.\right|^{2}=09$ & & & & 0.01 & $\begin{array}{c}0.1 \\
\text { Favours [early] }\end{array}$ & $\begin{array}{c}10 \\
10 \\
\text { Favours [late] }\end{array}$ & 100 \\
\hline
\end{tabular}

Figure 7 (d) Biliary tract complications cholecystectomy within or after 4 weeks.

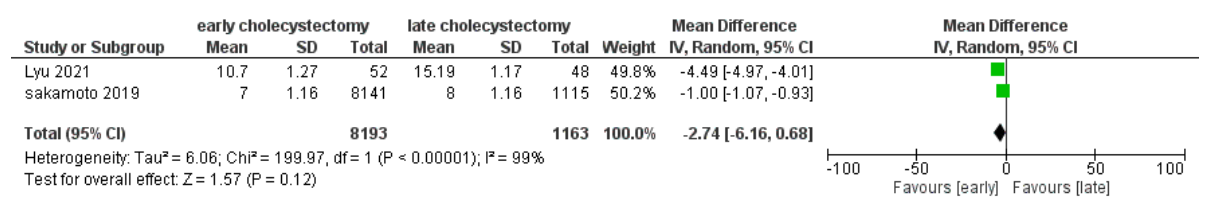

Figure 7 (e) Hospital stay cholecystectomy within or after 4 weeks.

Figure 7. Comparisons between cholecystectomy within or after 4 weeks after percutaneous cholecystostomy. 
medRxiv preprint doi: https://doi.org/10.1101/2021.06.06.21258426; this version posted June 12, 2021. The copyright holder for this preprint (which was not certified by peer review) is the author/funder, who has granted medRxiv a license to display the preprint in perpetuity.

It is made available under a CC-BY-NC 4.0 International license .

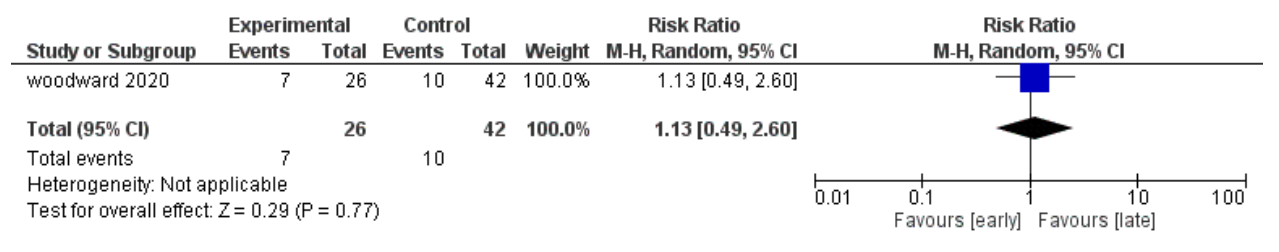

Figure 8 (a) Conversion to open cholecystectomy within or after 8 weeks.

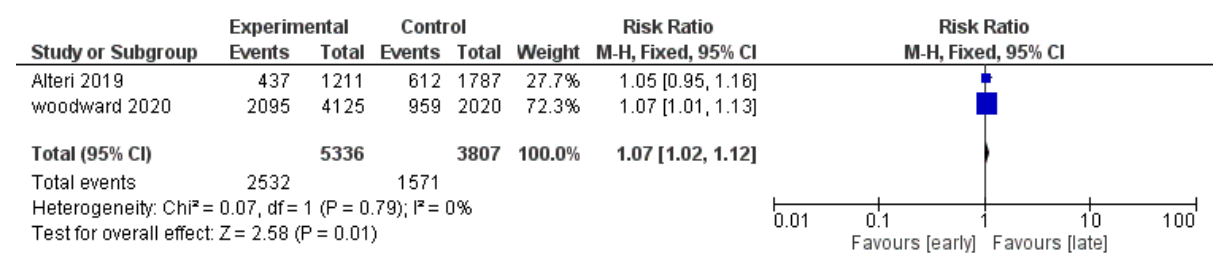

Figure 8 (b) Overall complications cholecystectomy within or after 8 weeks.

\begin{tabular}{|c|c|c|c|c|c|c|c|c|c|c|}
\hline Study or Subgroup & \multicolumn{2}{|c|}{ Early } & \multicolumn{2}{|c|}{ late } & Weight & \multicolumn{2}{|l|}{ Risk Ratio } & \multicolumn{2}{|c|}{$\begin{array}{c}\text { Risk Ratio } \\
\text { M-H, Random, } 95 \% \mathrm{Cl}\end{array}$} & \\
\hline woodward 2020 & 91 & 4125 & 40 & 2020 & $100.0 \%$ & $1.11[0.77,1.61]$ & & & & \\
\hline Total $(95 \% \mathrm{Cl})$ & & 4125 & & 2020 & $100.0 \%$ & $1.11[0.77,1.61]$ & & & & \\
\hline Total events & 91 & & 40 & & & & & & & \\
\hline $\begin{array}{l}\text { Heterogeneity: Not } \\
\text { Test for overall effec }\end{array}$ & $\begin{array}{l}\text { plicable } \\
Z=0.58\end{array}$ & $(P=0.5$ & & & & & 0.01 & $\begin{array}{l}0.1 \\
\text { Favours [early] }\end{array}$ & ]$^{1} \begin{array}{c}10 \\
\text { Favours [late] }\end{array}$ & 100 \\
\hline
\end{tabular}

Figure 8 (c) 90 days mortality cholecystectomy within or after 8 weeks.

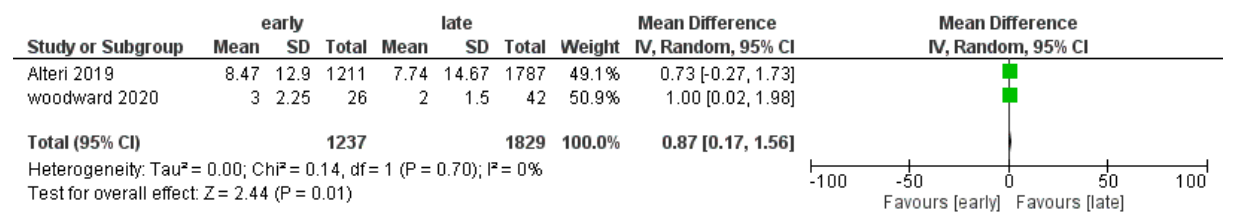

Figure 8 (d) Hospital stay cholecystectomy within or after 8 weeks.

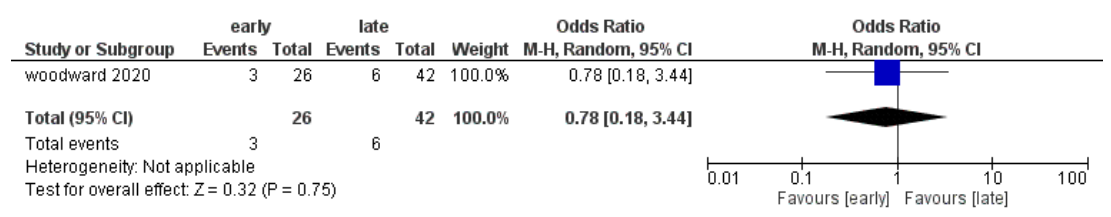

Figure 8 (e) Subtotal cholecystectomy within or after 8 weeks. 
medRxiv preprint doi: https://doi.org/10.1101/2021.06.06.21258426; this version posted June 12, 2021. The copyright holder for this preprint (which was not certified by peer review) is the author/funder, who has granted medRxiv a license to display the preprint in perpetuity.

Figure 8. Comparisons between cholecystectomy within or after 8 weeks after percutaneous cholecystostomy. 